\title{
The Cluster-Tray Method for Rapid Measurement of Solute Fluxes in Adherent Cultured Cells
}

\author{
Gian C. Gazzola ${ }^{* 1}$ Valeria Dall'Asta, ${ }^{*}$ Renata Franchi-Gazzola, \\ AND MORRIS F. WHITE ${ }^{\dagger}$ \\ *Istitute di Patologia Generale, Università di Parma, 43100 Parma, Italy; and † Department of Biological \\ Chemistry, The University of Michigan Medical School, Ann Arbor, Michigan 48109
}

Received February 9, 1981

\begin{abstract}
The use of an inexpensive and simple modification of Costar 24-well cluster trays is described in a rapid and reproducible method for measuring substrate fluxes in adherent cultured eukaryotic cells.
\end{abstract}

Several techniques involving cell suspensions or cells attached to tissue culture dishes or cover slips have been described for measuring the flux of radioactively labeled substrates across the plasma membrane of eukaryotic cells (1-6). All these approaches are time consuming and cumbersome on a large scale. In this report we describe the construction of simple equipment based on the Costar 24-well tissue culture cluster dish to facilitate the measurement of transport in adherent animal cells maintained in tissue culture. The technique is easy to set up, relatively inexpensive, convenient, and allows rapid as well as long-term assays. It has been successfully used in four laboratories ${ }^{2}$ and with four different cell types (human skin fibroblasts, hepatoma tissue culture cells, Chinese hamster ovary cells, freshly isolated hepatocytes in primary culture). Recently, results obtained using this cluster-tray tech-

' To whom correspondence should be addressed.

${ }^{2}$ Dr. Gian C. Gazzola, Istitute di Patologia Generale, Unversità di Parma, 43100 Parma, Italy; Dr. Halvor N. Christensen, Department of Biological Chemistry, University of Michigan, Ann Arbor, Mich. 48109; Dr. Dale L. Oxender, Department of Biological Chemistry, University of Michigan, Ann Arbor, Mich. 48109; Dr. Michael S. Kilberg, Department of Biochemistry and Molecular Biology, University of Florida, Gainesville, Fla. 32610 . nique have been reported $(7,8)$, but the equipment adopted, its construction features, and reliability tests have not been described.

\section{MATERIALS AND METHODS}

Cell culture. Human skin fibroblasts (9), hepatoma tissue culture (HTC) $)^{3}$ cells (10), normal rat hepatocytes (11), and Chinese hamster ovary (CHO) cells (12) were cultured as previously described except that Medium 199 (Gibco) supplemented with antibiotics was used for fibroblasts and HTC cell cultures. All media were buffered with $25 \mathrm{mM} \mathrm{NaHCO}_{3}$ at $\mathrm{pH} \mathrm{7.4,} \mathrm{maintained} \mathrm{in}$ a $37^{\circ} \mathrm{C}$ humidified atmosphere of $5 \% \mathrm{CO}_{2} /$ air, and supplemented with either $10 \%$ fetal calf serum (fibroblasts, HTC cells, hepatocytes) or $2.5 \%$ fetal calf serum plus $2.5 \%$ calf serum ( $\mathrm{CHO}$ cells) obtained from Flow Laboratories. Stock cultures of fibroblasts and HTC cells were maintained in $75-\mathrm{cm}^{2}$ culture flasks (Corning, No. 25110) and prepared for transport assay by seeding approximately $4 \times 10^{4}$ cells into each $2-\mathrm{cm}^{2}$

\footnotetext{
${ }^{3}$ Abbreviations used: HTC, hepatoma tissue culture cells; $\mathrm{CHO}$, Chinese hamster ovary cells; EBS modified Earle's balanced salt solution; MeAIB, 2-(methylamino)isobutyric acid.
} 
well of a Costar 24-well tissue culture cluster dish (Costar No. 3524), and allowed to grow to confluency in $1 \mathrm{ml}$ of medium for about 5 days. Rat hepatocytes were freshly isolated as described previously (13) and $1.5 \times 10^{5}$ cells were seeded into each $2-\mathrm{cm}^{2}$ well of a Costar tray. Hepatocytes were used after 24 $\mathrm{h}$ in primary culture. $\mathrm{CHO}$ cells were grown in glass bottles, seeded into the wells at a density of $1.2 \times 10^{5}$ cells, and used after 24 $\mathrm{h}$ of growth.

Construction of wash trays. In order to wash attached cell monolayers rapidly and simultaneously in the 24 wells of the cluster tray as required by the experimental protocol, "wash trays" were constructed consisting of twenty-four $12 \times 75-\mathrm{mm}$ Falcon tubes (Falcon Plastics, Los Angeles, Calif.), cut $35 \mathrm{~mm}$ from the bottom and glued with polystyrene cement into $12.5-\mathrm{mm}$ holes drilled into the cluster tray top (see Fig. 1). When this modified cover is in place on the cluster tray, the open end of each tube is centered over each well. It is good strategy to build several wash trays so they can be charged with the appropriate solutions before an experiment. A photograph of the complete assembly is provided in Fig. 2.

Construction of experiment trays. Initiation of a transport experiment by adding $200 \mu \mathrm{l}$ of a particular radioactive substrate (or a small volume of another substance depending on ones experimental goal) to each well of the cluster tray is accomplished with the "experiment tray." This assembly is sim-
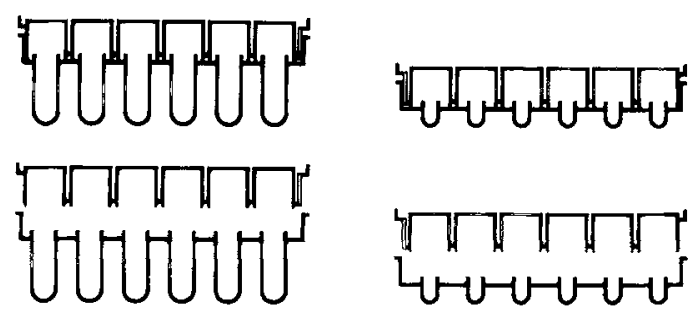

FIG. 1. Schematic drawings of longitudinal sections of a wash tray (left) and an experiment tray (right). ilar to the wash tray except that $8.5 \times 12$ mm polystyrene tubes ("indiwell" m74A, Dynatech Laboratories, Alexandria, Va.) are used in place of the Falcon tubes (see Fig. 1). By use of polystyrene cement, they are secured into $9-\mathrm{mm}$ holes drilled into the cluster-tray top. Polypropylene cmbedding capsules (beam size 00 , Polyscience, Inc., Warrington, $\mathrm{Pa}$. No. 0224) are also satisfactory and can be attached with cyanoacrylate adhesive. The open end of the indiwell should extend about 3 or $4 \mathrm{~mm}$ inside each well to ensure quantitative transfer of its contents from indiwell to cluster-tray well when this modified top is in place on a Costar tray. Rinsing the indiwells with distilled water and drying in a warm oven has proved sufficient to prepare the tray for the next experiment. A photograph of the complete assembly is shown in Fig. 2.

Transport assay. All amino acid transport experiments were carried out with cells maintained as monolayers in Costar cluster trays containing twenty-four $2-\mathrm{cm}^{2}$ wells unless otherwise specified. All washes and uptake measurements for fibroblasts, HTC cells, and rat hepatocytes are made with modified Earle's balanced salt solution (EBS) containing $0.1 \%$ D-glucose, $25 \mathrm{~mm}$ phosphate, $0.2 \mathrm{mM} \mathrm{Ca}^{2+}$, and $2.5 \mathrm{~mm}$ bicarbonate adjusted to $\mathrm{pH}$ 7.4. (Dulbecco's salts are used in experiments with $\mathrm{CHO}$ cells.) Monolayers are routinely washed once using a wash tray containing $2 \mathrm{ml}$ of fresh EBS in each Falcon tube and then incubated in 2 $\mathrm{ml}$ of fresh EBS for 30 to $60 \mathrm{~min}$ prior to an experimental assay to deplete endogenous amino acids (7). The wash trays are readily filled with EBS using an appropriate Repipet (Labindustries, Berkeley, Calif.). After the required time interval, the EBS is vigorously shaken from the wells into a receptacle. The experiment tray containing $0.2 \mathrm{ml}$ of EBS composed of $1 \mu \mathrm{Ci}$ of $\left[{ }^{3} \mathrm{H}\right.$ ]amino acid or 0.25 $\mu \mathrm{Ci}$ of $\left[{ }^{14} \mathrm{C}\right]$ amino acid plus the selected concentration of nonradioactive carrier (Sigma Chemical $\mathrm{Co}$.) in each indiwell is mated with 

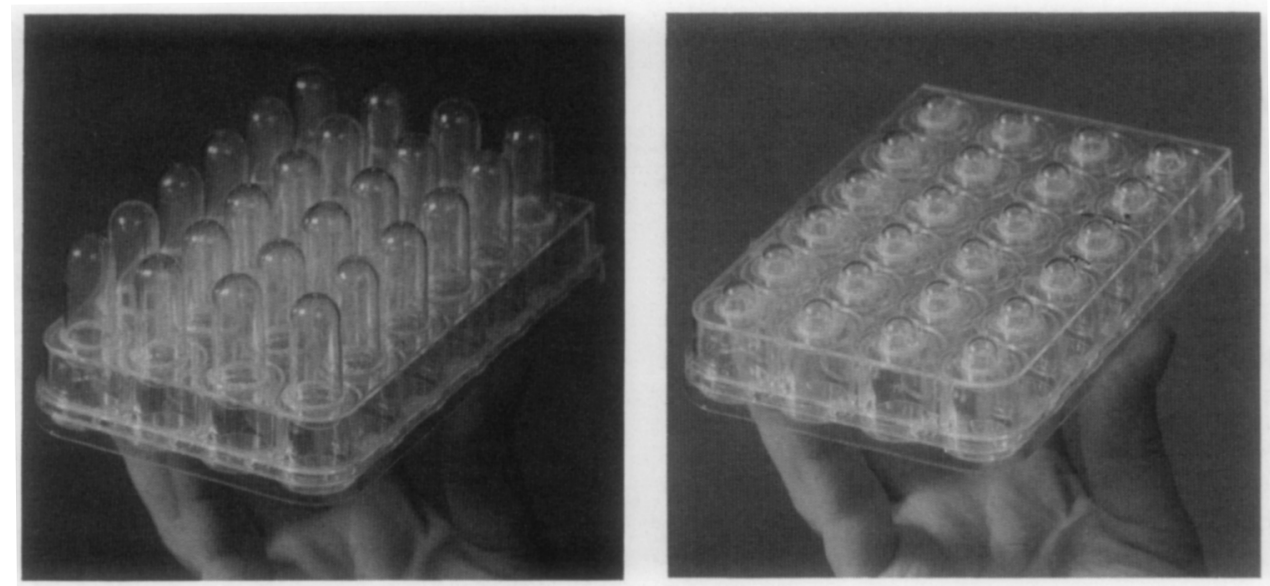

FIG. 2. Photographs of a wash tray (left) and an experiment tray (right). Details of their construction are provided in the text.

the appropriate cluster tray. The following labeled amino acids used in these studies were obtained from New England Nuclear Corporation: L- $\left[2,3-{ }^{3} \mathrm{H}\right]$ arginine, $82.7 \mathrm{Ci} /$ mmol, L- $\left[2,3-{ }^{3} \mathrm{H}\right]$ alanine, $30 \mathrm{Ci} / \mathrm{mmol}$; L$\left[\mathrm{G}^{3}{ }^{3} \mathrm{H}\right]$ serine, $4 \mathrm{Ci} / \mathrm{mmol} ; \quad \mathrm{L}-\left[4,5-{ }^{3} \mathrm{H}\right]-$ isoleucine, $104 \mathrm{Ci} / \mathrm{mmol} ; \mathrm{L}-\left[\mathrm{U}^{-14} \mathrm{C}\right] \mathrm{cys}-$ tine, $276 \mathrm{mCi} / \mathrm{mmol} ; \mathrm{L}-\left[\mathrm{U}-{ }^{14} \mathrm{C}\right]$ glycine, 100 $\mathrm{mCi} / \mathrm{mmol} ; \mathrm{L}-\left[1-{ }^{14} \mathrm{C}\right] \mathrm{MeAIB}, 59.6 \mathrm{mCi} /$ mmol; L-[U- $\left.{ }^{14} \mathrm{C}\right]$ proline, $225 \mathrm{mCi} / \mathrm{mmol}$; $\mathrm{L}$ $\left[\mathrm{U}-{ }^{14} \mathrm{C}\right.$ ]glutamine, $210 \mathrm{mCi} / \mathrm{mmol}$ ). The contents of each indiwell are simultaneously transferred to the 24 monolayers by briskly inverting the unit formed by mating the Costar cluster tray and the experiment tray. About $7 \pm 1 \mu$ lof buffer is retained in each indiwell following this procedure. Incubations are carried out at $\mathrm{pH} 7.4$ in a $37^{\circ} \mathrm{C}$ water bath for the desired time interval. Transport assays are terminated by quickly and deliberately shaking the uptake medium into a receiving vessel and immediately washing $(<10 \mathrm{~s})$ the 24 wells twice with 2 $\mathrm{ml}$ of ice-cold phosphate-buffered saline $\mathrm{(pH}$ 7.4) using the wash trays. The cluster tray is drained and the monolayers are extracted with $220 \mu \mathrm{l}$ of $5-10 \%(\mathrm{w} / \mathrm{v})$ trichloroacetic acid at room temperature for 15 to $30 \mathrm{~min}$. The acid is conveniently added to each well with a Distrivar manual dispenser (Gilson France S.A., Villiers-le-Bel, France, or Ranin Instrument Co., Inc., Woburn, Mass.). The soluble radioactivity in $200 \mu \mathrm{l}$ of extract is measured in $2 \mathrm{ml}$ of $3 \mathrm{a} 70 \mathrm{~B}$ complete counting cocktail (Research Products International Corp.) which displays 72 and $28 \%$ efficiency for ${ }^{14} \mathrm{C}$ and ${ }^{3} \mathrm{H}$, respectively. The acid is drained from the multiwell tray and the precipitated protein remaining is measured by dissolving the residue in 0.1 to 0.2 ml of $1 \mathrm{~N} \mathrm{NaOH}$ and assaying directly in the wells using the following modified Lowry procedure with bovine serum albumin as the standard (14). One milliliter of a solution containing disodium copper (II) (ethylenedinitrilo)-tetraacetate $(0.25 \mathrm{~g} / 1)$ obtained from Eastman Kodak Company, $\mathrm{Na}_{2} \mathrm{CO}_{3}$ $(20.0 \mathrm{~g} /$ liter $)$ and $\mathrm{NaOH}(4.0 \mathrm{~g} /$ liter $)$ is added to each well with swirling. For tenaciously attached cells addition of $1.0 \%(\mathrm{w} /$ v) sodium dodecyl sulfate to this solution serves to disperse the cells without otherwise affecting the color yield (15). After $10 \mathrm{~min}$, $0.1 \mathrm{ml}$ of Folin-Ciocalteau reagent, diluted 1:1 with water, is added to each well and the absorbance of the solutions is measured at $750 \mathrm{~nm}$ after $20 \mathrm{~min}$. The average protein content per well varies from $25 \mu \mathrm{g}$ (human 


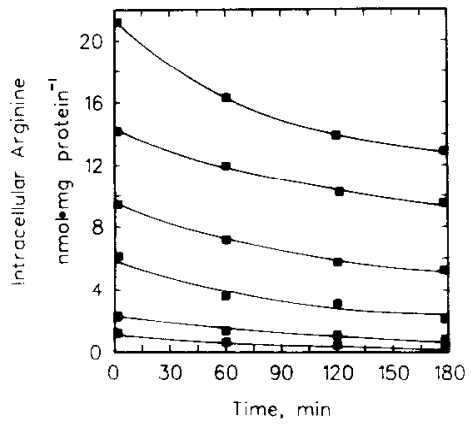

FIG. 3. Time courses of $\mathrm{L}$-arginine exodus from human fibroblasts into amino acid-free medium. Human fibroblasts were washed once and incubated in amino acidfree EBS for $60 \mathrm{~min}$ to deplete endogenous amino acid pools. The monolayers were then incubated with various concentrations $(1.0,0.75,0.40,0.20,0.10,0.06 \mathrm{mM})$ of $\mathrm{L}-\left[{ }^{3} \mathrm{H}\right]$ arginine for $30 \mathrm{~min}$ to load the cells to different intracellular concentrations. Thin-layer chromatography of the cell extract on cellulose has shown that no significant metabolism of arginine occurs during the time interval of this experiment (unpublished results). A single cluster tray was used for each of the time intervals studied. Exodus was initiated by quickly washing $(<5 \mathrm{~s})$ the monolayers in each well with EBS at $37^{\circ} \mathrm{C}$ and then incubating the cclls with $2 \mathrm{ml}$ of fresh EBS for $0,60,120$, or $180 \mathrm{~s}$. The experiment was terminated as usual. The data represent averages of duplicate measurements of the $\left[{ }^{3} \mathrm{H}\right]$ arginine remaining associated with the cells.

fibroblasts) to $120 \mu \mathrm{g}$ (HTC cells). The protein assay yields a linear relationship in this range.

\section{RESULTS AND DISCUSSION}

The cluster-tray assay described in this report for measuring substrate transport across the plasma membrane of adherent cultured cells yields several advantages: (i) $91 \%$ of the radioactive label extracted from the cells is measured; (ii) protein is measured directly in each well, thus minimizing pipetting and dilution errors; (iii) few cells are necessary per well $\left(10^{4}-10^{5}\right)$ permitting the study of experimental systems that yield low numbers of cells (i.e., freshly isolated fetal liver or mouse liver); (iv) consumption of expensive materials is minimized; $(v)$ many transport tests can be managed quickly in little space; (vi) the system can be set up rapidly and conveniently and yields reproducible results. Costar trays are suited to these applications because of their convenient size; their asymmetric design allows a unique positioning of the modified covers which minimizes errors during an experiment (see Fig. 2). The experiments described below demonstrate the validity of the technique and illustrate the problems that can be approached.

Table 1 is a list of kinetic constants determined for the uptake of L-arginine into HTC cells for six separate experiments. The mean standard errors of the parameters, $K_{m}$ and $V$, determined by fitting initial velocity data to the Michaelis-Menten equation by

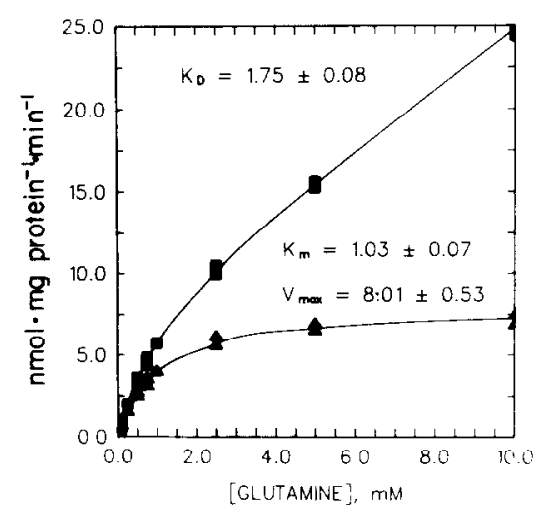

FIG. 4. The determination of the kinetic constants for L-glutamine uptake into cultured hepatocytes. Adult rat hepatocytes cultured for $24 \mathrm{~h}$ in complete medium (11) were washed once and incubated in amino acid-free EBS for $60 \mathrm{~min}$ to deplete endogenous amino acids. The cells were then incubated for $30 \mathrm{~s}$ with 12 concentrations of $\mathrm{L}-\left[{ }^{14} \mathrm{C}\right]$ glutamine between 0.025 and $10 \mathrm{mM}$ in duplicate using a single cluster tray. By graphical analysis the total uptake is a sum of a hyperbolic and a first-order term and was fitted to the modified Michaelis-Menten equation, $\nu=\left[V \mathrm{~S} / K_{m}+\mathrm{S}\right]+K_{\mathrm{D}} \mathrm{S}$ by Gauss-Newton nonlinear least-squares analysis described by Cleland (17). The kinetic parameters \pm standard error, $K_{m}$ (mM), $V\left(\mathrm{nmol} \cdot \mathrm{mg}\right.$ protein $\left.{ }^{-1} \cdot \mathrm{min}^{-1}\right)$, and $K_{\mathrm{D}}$ (nmol. $\mathrm{mg}$ protein $\left.{ }^{-1} \cdot \mathrm{min}^{-1} \cdot \mathrm{mM}^{-1}\right)$ are shown on the figure. The rectangular hyperbola obtained (A) after subtraction of the apparent nonsaturable component from the primary data describes uptake of glutamine by System $\mathrm{N}$. 
TABLE 1

Kinetic Constants for L-ARginine Uptake into HTC Cells Measured WITH THE Cluster-TRAY TECHNIQUE

\begin{tabular}{|c|c|c|c|c|c|}
\hline Exp No. & $\begin{array}{l}\text { No. of data } \\
\text { points }\end{array}$ & $K_{m} \pm \mathrm{SE}^{\mathrm{b}}(\mathrm{mM})$ & rse $\left(K_{\mathrm{m}}\right)^{b}$ & $\begin{array}{c}V \pm \mathrm{SE}^{b} \\
(\mathrm{nmol} \cdot \mathrm{mg} \\
\text { protein } \\
\left.\min ^{-1}\right)\end{array}$ & rse $(V)^{b}$ \\
\hline 1 & 45 & $0.145 \pm 0.006$ & 4.1 & $3.30 \pm 0.10$ & 3.0 \\
\hline 2 & 20 & $0.179 \perp 0.009$ & 5.0 & $3.20 \pm 0.06$ & 1.8 \\
\hline 3 & 20 & $0.190 \pm 0.010$ & 5.3 & $3.10 \pm 0.09$ & 2.9 \\
\hline 4 & 6 & $0.121 \pm 0.026$ & 21.7 & $4.00 \pm 0.19$ & 4.7 \\
\hline 5 & 22 & $0.183 \pm 0.012$ & 6.6 & $3.24 \pm 0.07$ & 2.1 \\
\hline 6 & 19 & $0.186 \pm 0.012$ & 6.5 & $3.10 \pm 0.09$ & 2.9 \\
\hline Average $\pm \mathrm{SD} ; \mathrm{rsd}^{c}$ & & $0.167 \pm 0.028 ; 16.7$ & & $3.3 \pm 0.3 ; 9.1$ & \\
\hline
\end{tabular}

${ }^{a}$ HTC cells were washed once and incubated in amino acid-free EBS for $60 \mathrm{~min}$ to deplete the internal amino acid pools. The cells were then incubated for $30 \mathrm{~s}$ with $\left[{ }^{3} \mathrm{H}\right]$ arginine between 0.01 and $1.0 \mathrm{~mm}$. The nonsaturable component of influx was insignificant $(<5 \%)$ and ignored when the data were fitted to the Michaelis-Menton equation by Gauss- Newton nonlinear least-squares analysis (16).

${ }^{b}$ The kinetic parameters \pm standard error and the corresponding relative standard error (rse) for the six separate experiments.

" The average kinetic constants \pm standard deviation and the relative standard deviation (rsd) for the six separate determinations.

the Gauss-Newton least-squares method (14) were 8 and $3 \%$ of the values, respectively. The variances are larger, of course, if the curve is based on fewer observations. The standard deviation for the average values of $K_{m}$ and $V$ for the six experiments were 15 and $10 \%$ of the respective parameters, larger than the former because of the inherent variation of the cell population from one experiment to another. Accordingly, this technique is reproducible.

Figure 3 shows a second application of the cluster-tray assay to transport. Human fibroblasts were loaded to different concentrations with L-arginine, and then the time course of exodus was observed. The manipulations described in the figure legend are minimal, straightforward, and rapid, thus decreasing error in the data and increasing confidence in the results. Collection of the 48 duplicate observations requires less than $1 \mathrm{~h}$.

The third example, shown in Fig. 4, related velocity to substrate concentration for the uptake of L-glutamine into primary cultures of rat hepatocytes. This amino acid has been shown in freshly isolated rat hepatocyte suspensions to be recognized by a saturable plasma membrane mediation designated System N; kinetic constants for its sodiumdependent uptake are $K_{m}=1.1 \mathrm{mM}$ and $V$ $=8.0 \mu \mathrm{mol} \cdot \mathrm{g}$ intracellular $\mathrm{water}^{-1} \cdot \mathrm{min}^{-1}$ (13). The Michaelis constant was duplicated by the technique described here, yielding a value of $1.03 \pm 0.07 \mathrm{~mm}$.

The final experiment shown in Table 2 compares the uptake of several amino acids into Chinese hamster ovary cells using on one hand the cluster-tray method and on the other hand a previously described technique using $35-\mathrm{mm}$ tissue culture dishes (12). The conclusion of interest here is that the relative standard deviation decreased by a factor of 3 from 20 to $7 \%$ when the cluster-tray assay was substituted. Similar improvements were seen in tests on rat hepatocytes (8).

We believe this procedure could simplify the study of numerous other problems in- 
TABLE 2

A Comparison of INfluX MEASUREMENTS for VArious Amino Acids into CHO Cells by Two Assay Procedures ${ }^{a}$

\begin{tabular}{|c|c|c|c|c|}
\hline \multirow[b]{2}{*}{ Amino acid } & \multicolumn{2}{|c|}{$35-\mathrm{mm}$ dish } & \multicolumn{2}{|c|}{ Cluster tray } \\
\hline & $\begin{array}{c}\mathrm{nmol} \cdot \mathrm{mg} \\
\text { protein }^{-1} \\
\min ^{-16}\end{array}$ & $\mathrm{rsd}^{c}$ & $\begin{array}{c}\mathrm{nmol} \cdot \mathrm{mg} \\
\text { protein } \\
\min ^{-16}\end{array}$ & $\mathrm{rsd}^{c}$ \\
\hline Alanine & $5.6 \pm 1.1$ & 19.8 & $7.98 \pm 0.64$ & 8.0 \\
\hline Serine & $6.5 \pm 1.0$ & 15.4 & $5.12 \pm 0.54$ & 10.5 \\
\hline Glutamine & $6.5 \pm 1.0$ & 15.4 & $8.86 \pm 0.22$ & 2.5 \\
\hline Cysteine $e^{d}$ & $9.6 \pm 1.0$ & 11.5 & $8.98 \pm 0.57$ & 6.3 \\
\hline $\mathrm{MeAIB}^{e}$ & $4.2 \pm 0.8$ & 19.0 & $2.64 \pm 0.02$ & 0.8 \\
\hline Glycine & $2.8 \pm 0.8$ & 28.6 & $2.54 \pm 0.13$ & 5.1 \\
\hline Proline & $1.9 \pm 0.6$ & 31.6 & $1.38 \pm 0.21$ & 15.2 \\
\hline Isoleucine & $2.4 \pm 0.4$ & 16.6 & $2.98 \pm 0.17$ & 5.7 \\
\hline Average rsd $^{f}$ & & 19.7 & & 6.8 \\
\hline
\end{tabular}

${ }^{a} \mathrm{CHO}$ cells were washed and incubated in modified Dulbecco's phosphate-buffered saline which contains $0.1 \%$ $(\mathrm{w} / \mathrm{v})$ glucose, $0.01 \%(\mathrm{w} / \mathrm{v})$ magnesium chloride, $0.01 \%(\mathrm{w} / \mathrm{v})$ calcium chloride, and choline salts replacing the sodium salts for $30 \mathrm{~min}$ to deplete the internal amino acids. The cells were then incubated with $0.2 \mathrm{mM}$ levels of the indicated $\left[{ }^{3} \mathrm{H}\right]$ - or $\left[{ }^{14} \mathrm{C}\right]$ amino acid in sodium containing Dulbecco's phosphate-buffered saline. The transport measurements were made with a previously described tissue culture dish assay (12) except that 35-mm dishes were used instead of $60 \mathrm{~mm}$ or the cluster-tray assay discussed in this report.

${ }^{b}$ Averages \pm standard deviation for four or five replicates $(35-\mathrm{mm}$ dish assay) and three or four replicates (cluster-tray assay) for each amino acid tested.

"Relative standard deviation.

${ }^{d}$ In all experiments with cysteine, dithiothreitol was present at 5 mм.

2-(methylaminoesobutyric) acid.

The average relative standard deviation for each method.

volving cell surface proteins, immunologic reactivity, and hormone function. The assemblies, sterilized with uv light or ethylene oxide, should be of value to investigators interested in making rapid changes of sterile media. Twelve-well Costar cluster trays with $4 \mathrm{~cm}^{2}$ of surface area per well serve satisfactorily, and might prove valuable when larger cell populations are required to observe a small response or for the study of subconfluent cells.

\section{ACKNOWLEDGMENTS}

The authors wish to thank Mark Shotwell and Dale Oxender for the use of their data with CHO cells. This experimental technique, initiated while G.C.G. was a visiting scientist in the laboratory of $H$. N. Christensen at Michigan, has been developed to the version described in the laboratory of G. G. Guidotti at Parma. This work was supported by the C. N. R. Gruppo Nazionale Struttura e Funzione di Macromolecole Biologiche and by the Ministero della Pubblica Istruzione, Roma, Italy, and (at Michigan) by a grant (HD01233) from the Institute of Child Health and Human Development, $\mathrm{Na}$ tional Institute of Health, U.S. Public Health Service.

\section{REFERENCES}

1. Foster, D. O., and Pardee, A. B. (1969) J. Biol. Chem. 244, 2675-2681.

2. Christensen, H. N. (1975) Biological Transport, p. 440, W. A. Benjamin, Inc., Reading, Mass.

3. LeCam, A., and Freychet, P. (1977) J. Biol. Chem. 252, 148-156.

4. Kletzien, R. F., Pariza, M. W., Becker, J. E., Potter, V. R., and Butcher, F. R. (1976) J. Biol. Chem. 251, 3014-3020.

5. Bass, R., and Englesberg, E. (1979) In Vitro 15 , 829-838.

6. Kristensen, L. O. (1980) J. Biol. Chem. 255, 5236 5243. 
7. Gazzola, G. C., Dall'Asta, V., and Guidotti, G. G. (1980) J. Biol. Chem. 255, 929-936.

8. Christensen, H. N., and Handlogten, M. E. (1981) Biochem. Biophys. Res. Commun. 98, 102-107.

9. Sly, W. S., and Grubb, J. (1979) in Methods in Enzymology (Jakoby, W. B., and Pastan, I. H., eds.), Vol. 58, pp. 444-450, Academic Press, New York.

10. Thompson, E. B. (1979) in Methods in Enzymology (Jakoby, W. B., and Pastan, I. H., eds), Vol. 58, pp. 544-552, Academic Press. New York.

11. Leffert, H. L., Koch, K. S., Moran, T., and Williams, M. (1979) in Methods in Enzymology (Jakoby. W. B., and Pastan, I. H., eds.), Vol. 58, pp. 536-544, Academic Press, New York.
12. Cecchini, G., Lee, M., and Oxender, D. L. (1976) J. Supramol. Struct. 4, 441-447.

13. Kilberg, M. S., Handlogten, M. E., and Christensen, H. N. (1980) J. Biol. Chem. 255, 40114019.

14. Wang, C.-S., and Smith, R. L. (1975) Anal. Biochem. 63, 414-417.

15. Lees, M. B., and Paxman, S. (1972) Anal. Biochem. 7, 184-192.

16. Cleland, W. W. (1967) in Advances in Enzymology (Nord, F. F., ed.), Vol. 29, pp. 1-32, Interscience, New York.

17. Cleland, W. W. (1979) in Methods in Enzymology (Purich, D. L., ed.), Vol. 63, pp. 103-138, Academic Press, New York. 